\title{
AN ANALYSIS CLASSROOM INTERACTION IN ENGLISH SUBJECT AT SENIOR HIGH SCHOOL
}

\author{
AN ARTICLE \\ Submitted in Partial Fulfillment of the Requirements \\ for the Degree of Sarjana Pendidikan
}

By:

DOSMA MUTIARA PURBA

Registration Number : 2123321022

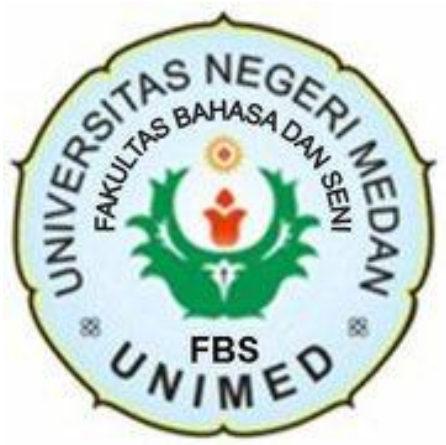

ENGLISH AND LITERATURE DEPARTMENT

FACULTY OF LANGUAGES AND ARTS

STATE UNIVERSITY OF MEDAN

2017 


\title{
ARTIKEL \\ AN ANALYSIS CLASSROOM INTERACTION IN ENGLISH SUBJECT AT SENIOR HIGH SCHOOL
}

\author{
Disusun dan Diajukan oleh:
}

Dosma Mutiara Purba

NIM. 2123321022

Telah diverifikasi dan dinyatakan memenuhi syarat

Untuk diunggah pada jurnal online

Medan, Juli 2017

Menyetujui

Dosen Pembimbing I

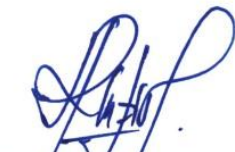

Rafika bey i Nasution, M.Hum.

NIP.19780108200501 2003
Dosen Pembimbing II

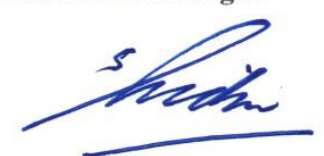

Drs. Lidiman S.M. Sinaga, M.Hum. NIP.19580722 1984121001

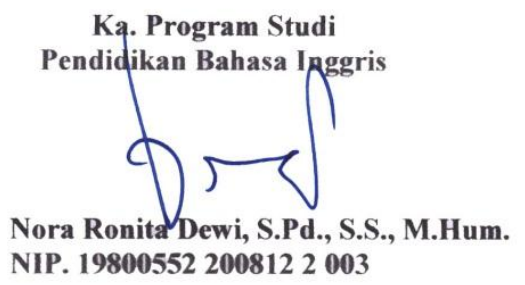




\title{
AN ANALYSIS CLASSROOM INTERACTION IN ENGLISH SUBJECT AT SENIOR HIGH SCHOOL
}

\author{
*Dosma Mutiara Purba* \\ ***Rafika Dewi Nasution** \\ **Lidiman S.M. Sinaga**
}

\begin{abstract}
Purba, Dosma. Nim 2123321022. An Analysis Classroom Interaction in English Subject at Senior High School. A Thesis. Faculty of Languages and Arts, State University of Medan. 2017.

This study focuses on analyzing the process of classroom interaction through Flanders Interaction Analysis Category (FIAC) model. The objective was to decsribe how the teacher and students use the categories of classroom interaction in English class by using Flanders Interaction Analysis Category (FIAC) model. The data was found based on the data transcription . the source of the data was the utterances between English teacher and 10th grade students at SMA N 2 Doloksanggul. The instruments for the data collection was video recording. The data analysis applied descriptive qualitative research. It was found that the total percentage each categories classroom interaction were Accepts Feeling (1.1\%), Praise and Encourages (2.4\%), Accepts Ideas of Students (1.2\%), Asks Questions (18.8\%), Lecturing (25\%), Giving Directions (17.8\%), Critizising or justifying authority (2\%), Student Talk Response (15.3\%), Student Talk Initation (1.9\%), Silence or Confusion (14.5\%). The dominant category of Teacher Talk in English classroom interaction at SMA N 2 Doloksanggul was Lecturing (25\%). While The dominat category of Students Talk was Students Talk Response (15.3\%).
\end{abstract}

Keywords : Teacher Talk, Student Talk, Flanders Interaction Analysis

Categories (FIAC) model.

\footnotetext{
*Graduate status

** Lecturer status
} 


\section{INTRODUCTION}

\section{Background of the Study}

One of the most important parts in teaching and learning process in the class is the classroom interaction.Classroom interaction is essential for the success of teaching and learning process. Classroom interaction refers to a technique consisting of objective and systematic of observation of the classroom events .

Classroom Interaction is necessary and useful as an educational strategy to enhance learning. The concept of classroom interaction plays a significant role in the process of second language learning. In fact the considerable interest in the role of interaction in the context of learning became an important factor for the researchers of this field, because it creates opportunities for the classroom community to develop knowledge and skills. As far as the speaking skill is concerned, we will try to shed some light on this skill which is considered the most desirable skill to be mastered by the vast majority of SL learners.

Analysis classroom interaction is appropriate by using Flanders' Interaction Analysis Categories System (FIACS). Flander technique is appropriate for analyzing the students' and teacher's talk at EFL context since the technique is to measure how much the teacher and students take talking during teaching and learning process. FIA system was designed to categorize the types and quantity of verbal interaction in the classroom and to plot the information on a matrix so that it could be analyzed and interpreted. The results gave a picture as to who was talking in the classroom, how much and kind of talking that took place. 
FIA became widely used coding system to analyze and improve teacher student interaction pattern. In fact, both EFL teachers and students are required to talk in the classroom. Besides that, Flander (1970) divides teacher talk (accepts feelings, praises or encourages, accepts or uses ideas of students, asks questions, lectures, gives direction, and criticizes or uses authority), students talk (response and initiation), and silence (period of silence or confusion).

Because FIACS technique is to know how much the teachers' and students' talking time and characteristics in classroom interaction, according to Flander (1970), the researcher who wants to use FIAC has to do plotting a coded data with a constant time before putting the data into observation tally. It is intended for knowing the calculating and characteristics of the teachers and students talk in the classroom. FIAC suggests that the constant time referring to every three seconds. It means that the researchers who wants to use FIACS technique has to use every three seconds to decide which one the best category of teacher talk, students talk, or silence should be written down to put in the observation sheet.

Based on the researcher's teaching experience in SMA N 2 Doloksanggul, it was found that the common interaction occured in the classroom that the students would participate to talk if the teacher initiated, encouraged, and asked to students to talk. The teacher was too dominant in talking than the students. In fact, the categories of teacher talk had great influence to make the students to talk in the classroom. In addition in the classroom interaction teacher just focused to some students who were clever and more active than the shy students. That was 
the basic reason why the researcher wanted to find out the common interaction that occured in the classroom whether the students participated in the interaction process or not. Then, to know how much the teacher and students spent time to talk during teaching and learning process.

Based on the writer's experience above, the writer wants to analyze how do the teacher and the students use the categories of classroom interaction in English Class, And the dominant category used by the teacher and the students in English classroom interaction.

\section{LITERATURE REVIEW}

\section{Definition of Classroom Interaction}

In Communicative Language Teaching (CLT), classroom interaction is really encouraged to occur in the EFL classroom. Classroom interaction will make the students interested in communicating at the classroom. Goronga (2013) asserts that classroom interaction makes the students participating in the teaching and learning process. It means that classroom interaction encourages students to involve.

Equally important, students are not the only participant in the classroom interaction since the teacher is also a participant. According to Dagarin (2004), classroom interaction is an interaction between teacher and students in the classroom where they can create interaction at each other. It means that classroom interaction is all of interactions that occur in the learning and teaching process. 


\section{The Nature of Classroom Interaction}

Interaction is the heart of communication, and communication itself, whether it is oral or written, is the central goal of the foreign language learning. In order to achieve that goal, the learners or the students need to cooperate and interact among themselves, between them and the teacher, or between them and someone else who are aware of language learning. In short, communication is derived from interaction since in communication there must be interaction between people who have something to share (Rivers, 1987).

\section{a. Aspects of Classroom Interaction}

There are two aspects in classroom interaction, they are: negotiation of meaning and feedback. If both of these aspects are not available in the classroom, the process of teaching and learning will not be successful. Here is the explanation of those aspects.

1) Negotiation of meaning

Ellis and Barkhuizen (2005) define negotiation of meaning as the verbal exchanges that occur when the speakers seek to prevent the breakdown of the communication.

2) The role of feedback

Xiao hui (2010:46) states feedback as the response given by teacher to efforts by learner to communicate, which include the notion of error correction. It also refers to the informative responses to what learner says, for example, smiling or clarifying questions. 


\section{b. Interactional Strategies}

Walsh (2010:110) states there are three important features of classroom interactional competence. They are :

1) Classroom interactional competence is used as a language related to specific pedagogic goals and to the agenda of the moment.

2) Classroom interactional competence is used for facilitating interactional space for learning.

3) Classroom interactional competence is used for shaping learners meaningful contributions through the use of various strategies, for example scaffolding, paraphrasing, reinterpreting, and so on.

\section{Types of Classroom Interaction}

In the classroom interaction, the participant involved considered as the types of classroom interaction depending on who communicate with whom.

\section{a. Teacher-Learner Interaction}

This type of interaction as Coulthard (1977) mentions has received a great deal from teachers in a wide range of disciplines. It happens between the teacher and one learner or many other learners, that is to say a teacher takes a part in such interaction. He negotiates with his students the content of the course, asks questions, uses students ${ }^{\text {ee }}$ ideas, lectures, gives directions, criticizes or justifies student talk responses. 


\section{b. Learner-Learner Interaction}

Johnson (1995) supports that if learner-learner interaction is well structured and managed, then it can be an important factor of cognitive development, educational achievement of students and emerging social competencies. It can also develop the learnersee capacities through collaborative works. So, learners will establish social relationship through this kind of interaction, where the sense of learning community is promoted and isolation is reduced in the classroom.

\section{Flander Interaction Analysis Categories System (FIACS) Technique}

Flanders' interaction Analysis is developed by Flander (1970 cited in Subudhi 2011) that is coding categories of interaction analysis to know the quantity of verbal interaction in the classroom. This technique is one of important techniques to observe classroom interaction systematically. The Flander Interaction Analysis Category System (FIACS) records what teachers and students say during teaching and learning process. Besides that, the technique allows the teachers see exactly what kind of verbal interaction that they use and what kind of response is given by the students.

\section{a. Ten categories of Teacher Talk and Student Talk \\ 1. Teacher Talk}

Accepting Feeling 
Teacher accepts and clarifies the feeling tone of the students in a nonthreatening manner. Feelings may be positive or negative also includes predicting or recalling feelings.

Praising and Encouraging

Teacher praises or encourages student action or behaviour. Jokes that release tension but not at the expense of another individual, nodding head, or approval are included.

Accepting or using ideas of students

Teacher clarifies, builds or develops ideas suggested by a student. As teacher states more of his ideas, the category shifts to lecturing.

Asking questions

Teacher asks a question about content or procedure with the intent that a student answers.

Lecturing

Teacher gives facts or opinions about content or procedures; expresses his ideas, asks rhetorical questions.

Giving directions

Teacher gives directions, commands, or orders to which a student is expect to comply.

$>$ Critizing or justifying authority

Teacher gives statements which intended to change student behaviour from non -acceptable to acceptable pattern, states teacher authority and so forth. 
2. Students Talk

Student talk - response

Students talk in response to teacher. Teacher initiates the contact or solicits student statement.

$>$ Students talk - initiation

Students initiate the talk, including the response to teacher's statements which indicates the student is willing to talk.

3. Silent Moments

Silence or confusion

Pauses, short periods of silence and periods of confusion in which communication cannot be understood by the observer.

\section{Strength of FIACS Technique}

As a tool for analysis classroom interaction in the teaching and learning process, the Flander system has some strength. According to Evans (1970), there are two strength of using Flander. First of all, it provides an objective method for distinguishing teacher verbal interaction and characteristic since it represents an effort to count teacher verbal interaction. Last, it describes teaching and learning process .

A FIACS technique covers interaction between teacher and students. Therefore, through FIACS, the researcher will know the quantity of verbal interaction in the classroom. FIAC can change the teacher's teaching style. It means that when the teacher knows how much they spend their time talking in the 
classroom, they will know their quality in making the students active in the classroom. Making the students participate at the classroom interaction, the teacher has to create and design materials that make classroom interaction is dominant by students since students-centered is really required in Communicative Language Teaching (CLT).

\section{RESEARCH METHODOLOGY}

The design of this research is Descriptive Qualitative Design. In this study the researcher taken the data from the transcription of utterances between teacher and students interaction during teaching learning activity. The source of the data for this research were the English teacher and the Students of tenth grade students at SMA N 2 Doloksanggul. The classes was chose as the location of the research in grade $\mathrm{X}-1$. In order to get the data collection the observer conducted the class observation for 1 time meeting in the classroom and taken 90 minutes. The instruments was video recording. Video Recording was applied as the technique for capturing natural interaction in the classroom in detail. The researcher used Flander's Interaction Analysis Categories System (FIACS).

The procedures of this research were conducted as follows:

1. Transcribing the spoken data

2. Classifying the data

3. Giving a code number

4. Pairing the data 
5. Plotting the code number into a matrix

6. Drawing conclusion from the response

\section{RESULT AND DISCUSSION}

\section{Result}

After analyzing the data, observing and calculating the percentage in the classroom interaction in SMA N 2 Doloksanggul, the findings of the result can be presented as follows:

1. Ten types of interaction in the Flanders Interaction Analysis Category (FIACS) namely, (1) Accepts Feeling, (2) Praises and Encourages, (3) Accepts or Uses Ideas of Students, (4) Ask Questions, (5) Lecturing, (6) Giving Directions, (7) Critizicing or Justifying Authority, (8) Student Talk Response, (9) Student Talk Initation, (10) Silence or Confusion appeared while teaching learning process in SMP N 2 Babalan. Then, from the data transcription, the researcher found that there was interaction happened in the classroom. While, the common interaction that occured in the classroom was the students would participate to talk if the teacher asked to the students to talk. It was found that the total percentage each categories classroom interaction were Accepts Feeling (1.1\%), Praise and Encourages (2.4\%), Accepts Ideas of Students (1.2\%), Asks Questions (18.8\%), Lecturing (25\%), Giving Directions (17.8\%), Critizising or justifying authority (2\%), Student Talk Response (15.3\%), Student Talk Initation (1.9\%), Silence or Confusion (14.5\%). The dominant category of Teacher 
Talk in English classroom interaction at SMA N 2 Doloksanggul was Lecturing (25\%). While The dominat category of Students Talk was Students Talk Response (15.3\%).

2. The most dominant categories of classroom interaction that happened in SMA N 1 Doloksanggul was for the Teacher Talk, the dominat category was "Lecturing" that can see from the utterances and the percentage about $25 \%$. It showed when the teacher gave explanation the material to the students or giving the information to the students. For the Students Talk, the dominant category was "Students Talk Response" that can see from the utterances and the percentage about $15.3 \%$. It showed when the teacher gave question and students answered it fastly.

\section{Discussion}

Related to the teaching and learning process, classroom interaction is important one is used by teacher and students in the class. In doing the interaction in teaching learning process, based on the result during having observation all the categories were applied in the classroom interaction that suggested by Flanders. After conducting the research and calculating the interaction in the class, the researcher found that teacher talk was still high than students talk.

The teacher spent $25 \%$ in lecturing during the teaching and learning process. Meanwhile the students spent $15.3 \%$ in response the teacher during teaching and learning process. So, it can be concluded that teaching - learning process of English Subject in SMA N 1 Doloksanggul was still in teacher's 
dominant activity. Based on the result, the teacher still need to improve her performance while teaching-learning process and to help students get their goal by giving more opportunities to the students to speak in the class while teachinglearning process.

\section{CONCLUSIONS AND SUGGESTIONS}

\section{Conclusions}

1. The Teacher and Students use all the categories of the classroom interaction by applying Flanders Interaction Analysis Category (FIAC) model. The categories of classroom interaction easier to find through the data transcription which is coded before. While, pairing the number of categories of interaction is used to enter it into matrix. Then, from the matrix can simplify to calculate each category until get the percentage on it.

2. The dominant category of Teacher Talk in English classroom interaction at SMA N 2 Doloksanggul was Lecturing (25\%). While the lowest category was Accepts Feeling (1.1\%). The dominat category of Students Talk was Students Talk Response (15.3\%). While the lowest categories was Students Talk Initation (1.9\%).

\section{Suggestion}

It is better if the teacher not only spend the teaching-learning time by explaining the material or asking question to the students about the material, but 
also can organize some activities for the students to make the classroom interaction more effective. For example; teacher asks the students make a group and gives one topic of the material to discuss. After having discussion, each group presents their discussion result in front of the class. 


\section{REFERENCES}

Allwright, D and K. M. Bailey. 1991. Focus on the Language Classroom: An Introduction to Classroom Research for Language Teachers. Cambridge University Press.

Dagarin, Mateza. 2004. Classroom Interaction and Communication Strategies in Learning English as a Foreign Language. Sloven: Sloven University.

Flanders, N. 1970. Analyzing Teacher Behavior. New York: Addison-Wesley.

Garetsa Febby. 2014. An Analysis of Classroom Interaction. Bengkulu: University of Bengkulu.

Nugroho. 2010. Interaction in English as a Foreign Language Classroom (A Case of Two State Senior High Schools in Semarang in the Academic Year 2009/2010). Universitas Bengkulu: Indonesia.

Nurmasitah. 2010. A Study of Classroom Interaction Characteristics In A Geography Class Conducted In English: The Case At Year Ten of An Immersion Class In SMA $N 2$ Semarang. Semarang: Diponegoro University

Pujiastuti, Rini Triani. 2013. Classroom interaction : An Analysis of Teacher Talk and Student Talk in English for Young Learners (EYL). Bandung: University of Education

Rivers, Wilga M. 1987. Interactive Language Teaching. Cambridge: Cambridge University Press.

Sinclair and Coulthard. 1975. Towards an Analysis of Discourse: The English Used by Teachers and Pupils. London: Oxford University Press.

Veronica. 2015. The Instructional Process: A Review of Flanders Interaction Analysis in a Classroom Setting. International journal of Secondary Education. Vol.3 No. 5, pp. 43-49 .

Zhao Shou. 2011. Classroom Interaction Analysis Techniques for Classroom Teachers. Singapore: Nanyang Technological University. 